

\title{
PENGARUH SENAM AEROBIK TERHADAP PENURUNAN TEKANAN DARAH PADA PENDERITA HIPERTENSI
}

\author{
Lina Indrawati \\ Sekolah Tinggi Ilmu Kesehatan Medistra Indonesia \\ Email :aisyah150416@gmail.com,081316317244
}

\begin{abstract}
ABSTRAK
Hipertensi telah menjadi masalah utama dalam kesehatan dunia. WHO memperkirakan sekitar 80\% kenaikan kasus hipertensi akan terjadi pada tahun 2025 terutama di negara berkembang dari sejumlah 639 juta kasus di tahun 2000 menjadi 1,15 milyar di tahun 2025. Intervensi senam aerobik sebagai terapi non farmakologi mampu menurunkan tekanan darah sesudah diberikan terapi selama 30-45 menit, melakukan senam aerobik dapat mendorong jantung bekerja lebih optimal, meningkatkan frekuensi jantung dan menaikan kekuatan pemompaan jantung yang baik terhadap kebutuhan oksigen, dan jantung tidak perlu berdenyut dengan cepat untuk memompa darah sehingga akan menyebabkan kecepatan jantung menurun, penurunan curah jantung dan penurunan resistensi perifer total, sehingga terjadi penurunan tekanan darah. Mengetahui pengaruh senam aerobik terhadap penurunan tekanan darah pada penderita Hipertensi di Puskesmas Jati Asih 2017. Penelitian ini merupakan jenis penelitian quasi eksperimen dengan menggunakan one group pre-test and post-test design tanpa kontrol dengan sampel sebanyak 30 orang. Pengaruh senam aerobik terhadap penurunan tekanan darah pada penderita hipertensi dianalisis dengan menggunakan uji statistic t-test. Ada pengaruh senam aerobik terhadap penurunan tekanan darah pada penderita hipertensi ( $p$ value $=0,000 ; \alpha=0,05$ ) Pemberian senam aerobik efektif menurunkan tekanan darah pada penderita hipertensi. Peneliti menyarankan untuk menerapkan intervensi senam aerobik ini di Puskesmas Jatiasih Bekasi.
\end{abstract}

\section{Kata kunci $\quad$ : Senam Aerobik, Tekanan Darah, Penderita Hipertensi \\ THE EFFECT OF AEROBIC EXERCISE ON BLOOD PRESSURE DECREASED FOR HYPERTENSION PATIENTS}

\begin{abstract}
Hypertension has become a primay problem in world health. WHO estimates that approximately $80 \%$ increase in cases of hypertension will happen in the year 2025, especially in developing countries from 639 million cases in 2000 to 1.15 billion in 2025. Aerobic exercise interventions as non-pharmacological therapy can lower blood pressure after 30 th therapy -45 minutes, doing aerobic exercise can encourage the heart to work more optimally, increase the heart rate and increase the pumping power of the heart is good against oxygen demand, and the heart does not need to beat rapidly to pump blood so that will cause heart rate decreased, decreased cardiac output and decreased Total peripheral resistance, resulting in a decrease in blood pressure. To determine the effect of aerobic exercise on blood pressure decrease in hypertension patients at Puskesmas Jati Asih 2017. This research is a type of experimental research using one group pre-test and post-test design without control with a sample of 30 people. The effect of aerobic exercise on blood pressure decrease in hypertension patients was analyzed by using t-test statistic test. There is influence of aerobic exercise to decrease blood pressure in hypertensive patient ( $p$ value $=0,000 ; \alpha=$ 0,05). Giving aerobic exercise effectively lowers blood pressure in people with hypertension. Researchers suggest to apply this aerobic exercise intervention at Puskesmas Jatiasih Bekasi.
\end{abstract}

Keywords

: Aerobic Exercise, Blood Pressure, Hypertension Patients 


\section{PENDAHULUAN}

Peningkatan kesehatan semakin lama semakin digalakkan selaras dengan perkembangan zaman. Semua bertujuan untuk mencapai derajat kesehatan sesuai ketentuan organisasi kesehatan dunia yang meliputi kesehatan jasmani, rohani dan social, bukan semata-mata tidak adanya penyakit atau kelemahan untuk mencapai maksud tersebut. Kesehatan jasmani dan rohani telah diupayakan dalam berbagai alternatif tindakan seperti pemeliharaan kesehatan badan dengan kebiasaan berolahraga. Latihan fisik yang teratur dapat menyebabkan perbaikan kebugaran jasmani. Kebugaran jasmani merupakan hal yang selalu didambakan oleh setiap individu maupun masyarakat. ${ }^{1}$ Perubahan tingkat kesehatan memicu transisi epidemiologi penyakit degeneratif atau penyakit yang tidak menular, salah satu penyakit tidak menular adalah hipertensi (tekanan darah tinggi). ${ }^{2}$ Hipertensi berarti peningkatan tekanan darah secara tidak wajar dan terus menerus karena rusaknya salah satu atau beberapa faktor yang berperan mempertahankan tekanan darah tetap dalam keadaan normal. ${ }^{2}$

Hipertensi adalah peningkatan tekanan darah secara tetap khususnya, tekanan diastolik melebihi 95 mmHg. $^{3}$ Pravalensi hipertensi telah menjadi masalah utama dalam kesehatan dunia. WHO memperkirakan sekitar 80\% kenaikan kasus hipertensi akan terjadi pada tahun 2025 terutama di negara berkembang dari sejumlah 639 juta kasus di tahun 2000 menjadi 1,15 milyar di tahun 2025. Indonesia sebesar 31,7\%. Cakupan diagnosis hipertensi oleh tenaga kesehatan hanya mencapai $24,0 \%$ dengan kata lain sebanyak $76,0 \%$ kejadian hipertensi dalam masyarakat belum terdiagnosis. ${ }^{2}$ Belakangan ini banyak sekali program-program kebugaran jasmani yang bisa di lakukan untuk menurunkan tekanan darah diantaranya adalah senam aerobik. Senam aerobik merupakan latihan yang menggunakan seluruh otot terutama otot-otot besar, secara terus-menerus, berirama, maju dan berkelanjutan. ${ }^{4}$ Penelitian populasi tentang latihan fisik dan kesehatan menunjukan bahwa gaya hidup kurang aktif menempatkan anda pada resiko penyakit kronis termasuk penyakit jantung. Latihan fisik yang teratur berkaitan dengan banyak manfaat kesehatan, termasuk mencegah dan menurunkan tekanan darah tinggi. ${ }^{1}$
Latihan fisik secara teratur mengurangi tekanan darah dan secara luas direkomendasikan oleh Amerika dan Eropa Hypertensives guidelines untuk latihan aerobik secara teratur, selama 30 sampai 45 menit setiap hari. Olahraga yang dilakukan teratur seperti melakukan senam aerobik mengurangi tekanan darah sistolik 3 sampai $5 \mathrm{mmHg}$ dan tekanan darah diastolik 2 sampai $3 \mathrm{mmHg}$. Pada hipertensi efek ini bahkan lebih jelas menunjukkan penurunan rata-rata $7 \mathrm{mmHg}$ sistolik dan $5 \mathrm{mmHg}$ diastolik untuk saat ini. ${ }^{5}$ Dengan latihan aerobik secara teratur, partisipan mampu menurunkan tekanan sistolik dan diastolik masing-masing rata-rata 11 dan 9 $\mathrm{mmHg}$, dengan intensitas sedang memberikan dampak baik terhadap manfaat penurunan tekanan darah. ${ }^{1}$ Olahraga menyebabkan perubahan besar pada sistem sirkulasi dan pernapasan dimana keduanya berlangsung bersamaan sebagai respon homeostatik. Latihan olahraga yang sering digunakan pada penderita hipertensi adalah olahrga aerobik. Banyak bentuk olahraga aerobik yang dapat ditempuh oleh pasien hipertensi salah satunya senam aerobik. ${ }^{6} \quad$ Olahraga teratur senam aerobik dapat menurunkan tekanan sistolik maupun diastolik pada orang dengan hipertensi tingkat ringan. Namun pada kenyataannya pasien hipertensi berkunjung jika hanya memiliki keluhan saja dan pengobatan tidak dilakukan secara rutin, selain itu pasien yang datang tersebut tidak mengetahui metode olahraga yang baik terutama pada senam. ${ }^{7}$

Hasil penelitian yang melibatkan 34 responden tentang pengaruh senam aerobik low impact terhadap tekanan darah pada penderita hipertensi. Adapun hasil yang diperoleh setelah dilakukan intervensi kelompok eksperimen didapatkan tekanan darah sistolik dan diastolik memiliki penurunan tekanan dengan perbedaan skor rata-rata sistolik 11,53 dan diastolik 9,58, maka dapat disimpulkan bahwa ada perbedaan yang sangat signifikan antara mean tekanan darah sistolik dan diastolik sebelum dan sesudah intervensi pada kelompok eksperimen senam aerobik low impact. $^{7} \quad$ Pada penelitian yang dilakukan Sulastri (2015) menyimpulkan bahwa terdapat pengaruh senam lansia terhadap tekanan darah sistolik dan diastolik pada lansia hipertensi di Puskesmas Kalijambe Sragen yang dilaksanakan selama 8 minggu Sedangkan penelitian yang dilakukan oleh peneliti selama 2 minggu, yaitu hanya 
seperempat dari lama penelitian yang dilakukan oleh peneliti sebelumnya. ${ }^{7}$

Study pendahuluan yang dilakukan di Puskesmas Jatiasih pada bulan April tahun 2017 didapatkan data penderita hipertensi pada periode 2016-2017 sebanyak 1.240 jiwa, penderita penyakit hipertensi di Puskesmas Jatiasih masuk kedalam 10 penyakit terbesar yang ada pada Puskesmas, program kesehatan yang sudah dilakukan oleh puskesmas untuk penderita yaitu melakukan kegiatan senam rutin setiap minggu, akan tetapi peminat penderita untuk mengikuti program rutin dipuskes masih minim yaitu hanya sebanyak $3,2 \%$ saja dari jumlah penderita hipertensi dipuskesmas, hal tersebut dikarenakan adanya keterbatasan waktu dan kurang berminatnya penderita untuk mengikuti program rutin yang diadakan oleh puskesmas. Berdasarkan paparan yang sudah di uraikan diatas peneliti tertarik untuk melakukan penelitian tentang pengaruh senam aerobik terhadap penurunan tekanan darah pada penderita hipertensi yang masih menjadi masalah di masyarakat umum, karena penderita hipertensi khususnya pada rentan usia 30-50 tahun yang masih belum termotivasi untuk melakukan latihan fisik atau berolahraga. Adapun tujuan dari penelitian ini untuk mengetahui pengaruh senam aerobik terhadap penurunan tekanan darah

pada penderita Hipertensi di Puskesmas Jati Asih Bekasi 2017.

\section{METODE}

Desain penelitian dalam penelitian ini adalah pretest-post tes design, Pretest-post tes design penelitian ini dilakukan dengan cara memberikan pre-test ( pengamatan awal ) terlebih dahulu sebelum intervensi, setelah itu di berikan intevensi lalu dilakukan post-tes (penilaian akhir). ${ }^{8}$ Populasi yang diambil dalam penelitian ini adalah para penderita hipertensi dipuskemas jatiasih sebanyak 1.240 penderita. Sampel yang di ambil dalam penelitian ini yaitu sebanyak 30 orang penderita hipertensi, dengan kriteria inklusi Penderita Hipertensi yang berobat dipuskesmas Jatiasih, Laki-laki atau perempuan dengan diagnosa hipertensi, Penderita dalam keadaan kompos mentis, berada dalam tempat penelitian pada saat dilakukan penelitian, Dapat berkomunikasi dengan baik dan kriteria eksklusi yaitu Penderita hipertensi sedang menjalankan pengobatan alternatif lainnya, Penderita hipertensi dengan komplikasi. ${ }^{8}$

Teknik pengambilan sampel adalah deng an menggunakan teknik Nonprobability Sampli $n g$ yaitu :Quota Sampling(Sampling kuota). ${ }^{11}$ Variabel yang akan diukur dalam penelitian ini adalah variabel independen dan variabel dependen. Variabel independen atau variabel bebas yaitu senam aerobik, sedangkan variabel dependen atau variabel terikat yaitu penurunan tekanan darah. ${ }^{8}$ Untuk mendapatkan informasi sesuai yang dibutuhkan. $^{10}$ peneliti menggunakan instrumen dalam penelitian ini adalah Sphigmomanometer, stetoskop, dan Lembar observasi. Tempat penelitian yang digunakan oleh peneliti yaitu di Puseksmas Jatiasih Bekasi 2017. Jenis data yang digunakan dalam penelitian ini yaitu jenis data primer dan data sekunder. Data primer merupakan data yang di ambil secara langsung oleh peneliti dari respondenya. Pengumpulan data dilaksanakan pada tanggal 22 Mei sampai 2 Juni, pengambilan data primer berhadapan langsung dengan responden dengan membagikan lembar inform concent pada responden penderita hipertensi. Data sekunder merupakan data yang diambil dari tempat penelitian yaitu di Puskesmas Jatiasih Bekasi dan dari buku-buku serta jurnal-jurnal yang menunjang pada penelitian yang berakitan dengan judul. ${ }^{10}$

Analisa data dalam penelitian ini menggunakan analisa univariat bertujuan untuk menganalisa variabel distribusi senam aerobik terhadap penderita hipertensi dipuskesmas Jatiasih Bekasi 2017. Analisa bivariat dilakukan untuk menganalisa pengaruh senam aerobik terhadap penurun tekanan darah pada penderita hipertensi dipuskesmas jatiasih 2017 dengan variabel dependen dilakukan dengan uji statistik Uji Paired T-test dimana ketentuan nilai probabilitas $\rho$ value $>0,05$ maka Ho gagal ditolak jika probabilitas $\rho$ value $<0,05$ maka Ho ditolak.

HASIL

A. Analisa univariat

Tabel 1

Distribusi Frekuensi dan Rata-Rata

Tekanan Darah Sebelum Melakukan Senam Aerobik di Puskesmas Jati Asih Bekasi

$\begin{array}{ccc}\begin{array}{c}\text { Tekanan } \\ \text { Darah }\end{array} & \text { N } & \begin{array}{c}\text { Mean } \\ (\mathbf{m m H g})\end{array}\end{array}$

\begin{tabular}{ccc}
\hline Sistolik & 30 & 160,67 \\
Diastolik & & 95,17
\end{tabular}

(Sumber : Master data statistika Lina, Juni 2017) 
Hasil analisa pada penlitian ini menggambarkan distribusi frekuensi rata-rata nilai tekanan pada penderita hipertensi sebelum dilakukan intervensi senam aerobik. Hasil penelitian terhadap 30 responden analisi univariat telah teridentifikasi rata tekanan darah pada penderita hipertensi sebelum melakukan senam aerobik adalah 160,67/95,17 mmHg.

Tabel 2

Distribusi Frekuensi dan Rata-Rata

Tekanan Darah Sesudah Melakukan senam aerobic di Puskesmas Jatiasih Bekasi

\begin{tabular}{ccc}
\hline Tekanan Darah & $\mathbf{N}$ & $\begin{array}{c}\text { Mean } \\
(\mathbf{m m H g})\end{array}$ \\
\hline Sistolik & 30 & 139,17 \\
Diastolik & & 84,50 \\
\hline
\end{tabular}

(Sumber : Master data statistika Lina, Juni 2017)

Hasil analisa pada penlitian ini menggambarkan distribusi frekuensi rata-rata nilai tekanan pada penderita hipertensi sesudah dilakukan intervensi senam aerobik hasil penelitian terhadap 30 responden didapat kan hasil analisi univariat telah teridentifikasi rata tekanan darah pada penderita hipertensi sesudah melakukan senam aerobik adalah $139,17 / 84,50 \mathrm{mmHg}$.

B. Analisa Bivariat

Table 3

Pengaruh Senam Aerobik Terhadap Penurunan Tekanan Darah Sistolik pada Penderita Hipertensi di Puskesmas Jati Asih Bekasi 2017

\begin{tabular}{|c|c|c|c|c|c|}
\hline Kelompok & $N$ & $\begin{array}{c}\mathrm{M} \\
(\mathrm{mmHg})\end{array}$ & t hitung & $\begin{array}{c}\text { t tabel } \\
(d f=29)\end{array}$ & p value \\
\hline Sebelum & & 156,67 & & & \\
\hline Sesudah & 30 & 133.67 & 13,202 & 1,699 & 0,000 \\
\hline
\end{tabular}

Berdasarkan hasil analisa bivariat dengan un uji komparasi paired t-test tentang penurunan tekanan darah sistolik sebelum dan sesudah melakukan senam aerobik di Puskesmas Jati Asih Bekasi dengan jumlah sampel sebanyak 30 responden $(n=30)$ didapatkan data bahwa $\mathrm{T}$ hitung $(13,202)>\mathrm{T}$ table $(1,699)$ dan nilai $\mathrm{P}(0,000)$ nilai alpha
$(0,05)$ yang berarti ada perbedaan tekanan darah sistolik pada penderita hipertensi sebelum dan sesudah melakukan senam aerobik, dimana tekanan darah sistolik sesudah melakukan senam aerobik lebih rendah $(\mathrm{m}=139,17 \mathrm{mmHg}) \quad$ daripada sebelum melakukan senam aerobik $(\mathrm{m}=160,67 \mathrm{mmHg})$.

Table 4

Pengaruh Senam Aerobik Terhadap Penurunan Tekanan Darah Sistolik pada Penderita Hipertensi di Puskesmas Jati Asih Bekasi 2017

\begin{tabular}{|c|c|c|c|c|c|}
\hline Kelompok & $N$ & $\begin{array}{c}\mathrm{M} \\
(\mathrm{mmHg})\end{array}$ & $t$ hitung & $\begin{array}{c}\text { t tabel } \\
(d f=29)\end{array}$ & p value \\
\hline Sebelum & & 95,33 & & & \\
\hline Sesudah & 30 & 85,00 & 37,796 & 1,699 & 0,000 \\
\hline
\end{tabular}

(Sumber : Master data statistika Lina, Juni 2017)

Berdasarkan hasil analisa bivariat dengan uji

komparasi paired t-test tentang penurunan

Asih Bekasi dengan jumlah sampel sebanyak tekanan darah diastolik sebelum dan sesudah melakukan senam aerobik di Puskesmas Jati 30 responden $(\mathrm{n}=30)$ didapatkan data bahwa $\mathrm{T}$ hitung $(37,796)>\mathrm{t}$ tabel $(1,699)$ dan nilai $\mathrm{p}$ $(0,000)<$ nilai alpha $(0,05)$ yang berarti ada 
perbedaan tekanan darah diastolik pada penderita hipertensi sebelum dan sesudah melakukan senam aerobik, dimana tekanan darah diastolik sesudah melakukan senam

\section{PEMBAHASAN}

\section{Analisa Univariat}

a. Mengidentifikasi rata-rata tekanan darah sebelum melakukan senam aerobik pada penderita hipertensi

Berdasarkan hasil penelitian yang dilakukan oleh peneliti menunjukan rata-rata tekanan darah sebelum melakukan senam aerobik memiliki rata-rata tekana darah sistolik $160,67 \mathrm{mmHg}$ yang menurut Joint National Comite (JNC) termasuk dalam kategori hipertensi stadium 2 bila tekanan darah sistolik mencapai $>160 \mathrm{mmHg}$ dan tekanan darah diastolik $95,17 \mathrm{mmHg}$ masuk dalam kategori hipertensi stadium 1 bila tekanan diastolik mencapai 90-99 mmHg. Hal tersebut dapat terjadi karena adanya dua faktor utama yaitu jantung yang memompa dengan kuat dan arteri yang sempit sehingga darah mengalir menggunakan tekanan untuk melawan dinding pembuluh darah. ${ }^{11}$

Berdasarkan anlisa peneliti peningkatan tekanan darah pada penderita hipertensi yang terjadi di puskesmas Jatiasih yaitu dikarenakan faktor keturunan yang dimana ada beberapa keluarga penderita hipertensi memiliki riwayat hipertensi, dan juga dari perilaku atau gaya hidup yang kurang baik yang dialami oleh penderita hipertensi, dimana penderita tidak memperhatikan pola makan yang baik, sehingga dapat menyebabkan terjadinya obesitas yang bisa menjadikan obesitas menjadi salah satu pencetus terjadinya hipertensi, karena secara fisiologis, obesitas di definisikan sebagai penumpukan lemak berlebih dijaringan. Ketidakseimbangan antara konsumsi kalori dengan kebutuhan energi yang disimpan dalam bentuk lemak yang menyebabkan jaringan lemak inaktif sehingga beban kerja jantung meningkat. Akibat dari obesitas para penderita cenderung menderita penyakit kardiovaskular seperti hipertensi dan Kurangnya berolahraga juga menjadi salah satu penyebab terjadinya hipertensi yang di alami oleh penderita hipertensi di Puskesmas Jatiasih karena kurangnya berolahraga mengakibatkan terjadinya kekakuan pembuluh darah yang dapat melemahkan daya tahan jantung sehingga jantung harus bekerja lebih keras untuk memompa jantung. aerobik lebih rendah $(\mathrm{m}=83,17 \mathrm{mmHg})$ daripada sebelum melakukan senam aerobik $(\mathrm{m}=95,17 \mathrm{mmHg})$.

Olahraga teratur adalah suatu kebiasaan yang memberikan banyak keuntungan seperti berkurangnya berat badan, tekanan darah, kadar kolesterol serta penyakit jantung. Dalam kaitannya dengan hipertensi, olahraga teratur dapat mengurangi kekakuan pembuluh darah dan meningkatkan daya tahan jantung serta paru-paru sehingga dapat menurunkan tekanan darah. Olahraga isotonik dengan teratur akan menurunkan perifer yang akan menurunkan tekanan darah. Diperkuat oleh Dimeo, dkk tahun 2012 dalam jurnal Aerobic Exercise Reduces Blood Pressure in Resistant Hypertension yang menyatakan bahwa Latihan fisik secara teratur mengurangi tekanan darah selama 30 sampai 45 menit setiap hari. Olahraga yang dilakukan teratur seperti melakukan senam aerobik mengurangi tekanan darah sistolik 3 sampai $5 \mathrm{mmHg}$ dan tekanan darah diastolik 2 sampai $3 \mathrm{mmHg}$. Pada hipertensi efek ini bahkan lebih jelas menunjukkan penurunan rata-rata $7 \mathrm{mmHg}$ sistolik dan $5 \mathrm{mmHg}$ diastolik untuk saat ini.

a. Mengidentifikasi rata-rata tekanan darah sesudah melakukan senam aerobik pada penderita hipertensi

Berdasarkan hasil analisa univariat yang telah teridentifikasi rata-rata penurunan tekanan darah pada penderita hipertensi sesudah melakukan senam aerobik selama 4 kali dalam 2 minggu dengan waktu 30-45 menit pada pagi hari adalah $20,50 \mathrm{mmHg}$ pada tekanan sistolik dan 10,17 $\mathrm{mmHg}$ pada tekanan diastolik. Dimana sebelum melakukan senam aerobik rata-rata tekanan darah sistolik pada penderita hipertensi $160,67 \mathrm{mmHg}$ termasuk pada kategori hipertensi stadium 2 tetapi setelah melakukan senam aerobik menunjukan penurunan menjadi $139,17 \mathrm{mmHg}$ termasuk pada kategori pra-hipertensi.

Sejalan dengan penelitian yang mengatakan bahwa dengan latihan senam aerobik secara teratur, partisipan mampu menurunkan tekanan sistolik dan diastolik masing-masing rata-rata 11 dam $9 \mathrm{mmHg}$. Walaupun banyak penelitian yang berfokus pada latihan dengan intensitas tinggi, seperti lari, bebrapa telah mengevaluasi dampak kegiatan yang lebih ringan seperti 
jalan kaki. Olahraga dengan intensitas sedang juga mempunyai dampak yang sama atau bahkan lebih baik terhadap manfaat menurunkan tekanan darah. Latihan aerobik diketahui mampu menurunkan tekanan darah pada orang dengan berat badan berlebih dan orang dengan berat badan normal secara signifikan. ${ }^{1}$ Berdasarkan analisa peneliti dengan melakukannya pengukuran tekanan darah yang dilakukan oleh peneliti bertujuan untuk mengetahui apakah ada perbedaan antara hasil ukur tekanan darah sebelum dan sesudah dilakukan intervensi senam aerobik. Berdasarkan data hasil pengukuran tekanan darah, rata-rata tekanan darah diastolik pada penderita hipertensi sebelum dilakukan senam aerobik adalah $95,17 \mathrm{mmHg}$ yang termasuk pada kategori hipertensi stadium 1 dan setelah mendapatkan intervensi senam aerobik menunjukan penurunan menjadi $84,50 \mathrm{mmHg}$ termasuk dalam kategori Pra-Hipertensi, sehingga bisa disimpulkan bahwa melakukan latihan fisik atau berolahraga salah satunya senam aerobik dapat menurunkan tekanan darah pada penderita hipertensi. Penurunan tekanan darah sistolik dan diastolik yang terjadi pada penderita hipertensi di Puskesmas Jati Asih Bekasi karena penderita rutin mengikuti latihan olahraga senam aerobik dengan baik. Melakukan senam aerobik dapat merilekskan pembuluh darah, semakin lama latihan olahraga dapat melemaskan pembuluh darah, sehingga pembuluh darah tidak menjadi kaku dan mengakibatkan tekanan darah akan menurun.

Semakin lama melakukan senam aerobik akan membuat pembuluh darah semakin rileks, tubuh akan menajdi semakin sehat dan juga akan menyebabkan penurunan tekanan darah tinggi dengan bertahap. Analisa di atas diperkuat oleh fetriwahyuni, dkk pada tahun 2015 dalam jurnal Pengaruh Senam Aerobik Low Impact Terhadap Tekanan Darah Penderita Hipertensi yang menyatakan bahwa Melakukan senam aerobik low impact dapat menurunkan tekanan darah yang terjadi karena pembuluh darah mengalami pelebaran dan relaksasi yang juga dapat mengurangi tahanan perifer. Penurunan tekanan darah juga dapat terjadi akibat aktivitas memompa jantung berkurang. Otot jantung pada orang yang rutin berolahraga sangat kuat, maka otot jantung dari individu yang rajin berolahraga berkontraksi lebih sedikit daripada otot jantung orang yang jarang berolahraga untuk memompakan volume darah yang sama. ${ }^{11}$

\section{2. analisa bivariat}

Berdasarkan hasil analisa bivariat dengan uji komparasi Paired Sample T-Test tentang tingkat tekanan darah pada penderita hipertensi sebelum dan sesudah dilakukan intervensi senam aerobik di Puskesmas Jatiasih bekasi dengan jumlah sampel 30 responden $(n=30)$ pada tekanan darah sistolik didapatkan data bahwa t hitung $(13,202)>\mathrm{t}$ tabel $(1,699)$ dan nilai $\mathrm{p}(0,000)<$ nilai alpha $(0,05)$ yang berarti ada perbedaan tekanan darah sisitolik pada penderita hipertensi sebelum dan sesudah dilakukan intervensi senam aerobik, dimana rata-rata tekanan darah sistolik sesudah melakukan senam aerobik lebih rendah $(m=139,17, \quad m m H g)$ dari pada sebelum dilakukannya intervensi senam aerobik $(m=160,67, \mathrm{mmHg})$.

Sedangkan pada tekanan darah diastolik pada pendrita hipertensi sebelum dan sesudah dilakukan intervensi senam aerobik di dapatkan hasil $\mathrm{t}$ hitung $(37,796)>\mathrm{t}$ tabel $(1,699)$ dan nilai $\mathrm{p}(0,000)<$ nilai alpha $(0,05)$ yang berarti ada perbedaan tekanan darah diastolik pada penderita hipertensi sebelum dan sesudah dilakukannya intervensi senam aerobik, dimana rata-rata tekanan darah diastolik sesudah dilakukan senam aerobik lebih rendah $(m=84,50, m m H g)$ dari pada sebelum dilakukannya intervensi senam aerobik $(m=95,17, \mathrm{mmHg})$.

Hasil analisa komparasi didapatkan hasil $\mathrm{t}$ hitung $(13,202 ; 37,796)>\mathrm{t}$ tabel $(1,699)$ dan nilai $\mathrm{p}(0,000 ; 0,000)<$ nilai alpha $(0,05)$. Sehingga dapat disimpulkan bahwa pada hasil uji hipotesis dinyatakan $\mathrm{H}_{\mathrm{o}}$ ditolak artinya ada pengaruh senam aerobik terhadap penurunan tekanan darah pada penderita hipertensi di Puskesmas jatiasih Bekasi. Penelitian ini sejalan dengan penelitian yang di lakukan oleh (Fetriwahyuni, 2015) bahwa hasil penelitian menunjukan terdapat pengaruh yang Signifikan dari senam aerobik low impact terhadap tekanan darah pada lansia penderita hipertensi di posyandu lansia kelurahan brebes. ${ }^{11}$

Senam aerobik berarti senam berirama karena saat melaksanakan selalu menggunakan alat musik atau sound system untuk mengiringi gerakan yang dilakukan dan selalu dihitung dengan ritme 1-8 dan diulang dua kali untuk setiap gerakannya. ${ }^{13}$ Senam aerobik adalah olahraga kesehatan bertingkat sasaran III (olahraga Aerobik) yang wujudnya adalah gerakan-gerakan senam. Oleh karena itu, senam aerobik sebagaiolahraga kesehatan harus memenuhi syarat pertama dan utama, yaitu olahraga aerobik dan syarat kedua yaitu 
berbentuk gerakan-gerakan senam. ${ }^{14}$ Aktivitas aerobik juga dikenal sebagai latihan kardiovaskular dan ketahanan. Latihan ini terdiri dari gerakan berulang yang melibatkan kontraksi kelompok otot besar lengan dan kaki, dan menggunakan oksigen untuk membantu membakar lemak sebagai sumber bahan bakar utama untuk daya aktivitas. Olahraga aerobik meningkatkan pernapasan dan detak jantung serta menyebabkan berkeringat, latihan aerobik adalah pusat dari setiap program kebugaran. Hampir semua penelitian mengenai manfaat olahraga untuk memerangi penyakit berkisar sekitar aktivitas kardiovaskular. ${ }^{1}$

Berdasarkan analisa peneliti perubahan tekanan darah yang bisa terjadi pada penderita hipertensi di Puskesmas Jatiasih yaitu yakni dari beberapa faktor, seperti menjaga gaya hidup dengan mengkonsumi makanan yang sesuai dengan kebutuhan tubuh, menjaga tubuh dari obesitas, dan juga bisa melakukan latihan fisik atau berolahraga, salah satu olahraga yang baik untuk penderita hipertensi yaitu dengan melakukan senam aerobik. Melakukan senam aerobik sama saja dengan kita menari yang di iringi dengan musik disetiap gerakannya, akan tetapi musik dan gerakan yang dilakukan pada senam aerobik mempunyai irama dan juga gerakan yang terstruktur seperti gerakan pemanasan, gerakan inti dan juga gerakan penutup sehingga para penderita bisa mengikuti gerakannya dengan baik. Berolahraga senam aerobik dengan rutin bisa membantu mendorong jantung bekerja lebih optimal, dimana olahraga untuk jantung mampu meningkatkan kebutuhan energi oleh sel, jaringan dan organ tubuh, meningkatkan frekuensi jantung dan menaikan kekuatan pemompaan jantung yang baik terhadap kebutuhan oksigen, dan jantung tidak perlu berdenyut dengan cepat untuk memompa darah seperti saat sebelum berolahraga secara teratur, sehingga akan menyebabkan kecepatan jantung menurun dan terjadi penurunan tekanan darah, oleh karena itu para penderita hipertensi di Puskesmas Jatiasih mengalami penurunan tekanan darah karena mereka rutin mengikuti olahraga senam aerobik. Diperkuat oleh Anggraini, tahun 2015 dalam jurnal Pengaruh Senam Aerobik Terhadap Tekanan Darah IbuIbu Penderita Hipertensi yang menyatakan bahwa Latihan fisik yang dianjurkan untuk penderita hipertensi salah satunya ialah senam aerobik low impact dengan cara berkelompok. Pada senam aerobik misalnya dari variasivariasi geraknnya yang banyak terutama gerakan dasar pada kaki dan jalan dapat memenuhi criteria continu, rhythmical, interval, progresif dan endurance (CRIPE) bisa melakukan olahraga secara continu untuk menjaga kesehatan dan kebugaran tubuh. ${ }^{15}$

\section{PENUTUP}

Berdasarkan hasil penelitian pengaruh senam aerobik terhadap penurunan teknanan darah pada penderita hipertensi di Puskesmas Jatiasih Bekasi dapat dibuat kesimpulan secara umum sebagai berikut ;

1. Rata-rata tekanan darah sistolik dan diastolik pada penderita hipertensi sebelum dilakukan intervensi senam aerobik $160,67 / 95,17 \mathrm{mmHg}$.

2. Rata-rata tekanan darah sistolik dan diastolik pada penderita hipertensi setelah dilakukan intervensi senam aerobik $139,17 / 84,50 \mathrm{mmHg}$.

3. Rata-rata Penurunan tekanan darah sistolik dan diastolik pada penderita hipertensi setelah dilakukan senam aerobik 20,50/10,17 mmHg.

4. Hasil uji normalitas data tekanan darah sistolik dan diastolik pada penderita hipertensi sebelum dan sesudah dilakukan intervensi senam aerobik, didapatkan data bahwa sebelum dilakukan intervensi senam aerobik pada tekanan darah sistolik nilai $\mathrm{p}$ $(0,344)>$ nilai alpha $(0,05)$, sesudah dilakukan intervensi senam aerobik didapatkan nilai $\mathrm{p}(0,439)>$ nilai alpha $(0,05)$, dan hasil uji normalitas tekanan darah diastolik pada penderita hipertensi sebelum dilakukan intervensi senam aerobik didapatkan nilai $\mathrm{p}(0,117)>$ nilai alpha $(0,05)$, sesudah dilakukan intervensi senam aerobik didapatkan nilai p $(0,069)>$ nilai alpha $(0,05)$ yang berarti pada tekanan darah sistolik dan diastolik data terdistribusi normal.

5. Hasil data penelitian didapatkan nilai $p$ value $(0,000)<$ nilai alpha $(0,05)$ yang berarti menunjukan bahwa ada pengaruh senam aerobik terhadap penurunan tekanan darah pada penderita hipertensi di Puskesmas Jatiasih Bekasi tahun 2017.

\section{DAFTAR PUSTAKA}

1. Casey \& Benson. (2012). Menurunkan tekanan darah. Bhuana ilmu popular, Jakarta

2. Marsiadi. (2016). Epidemiologi penyakit tidak menular. Cv transinfomedia, Jakarta

3. Wade. (2016). Mengatasi hipertensi. Nuasa Cendekia, Bandung 
4. Purwanto. (2011). Dampak senam aerobik terhadap penyandang hipertensi. Vol $4 ; 1$ di unduh pada tanggal 4 Maret 2017, jam 07:01WIB

5. Dimeo, pangonas, dkk. (2012). Aerobic exercise reduce blood pressure in resistant hypertension. Vol 60 : 653-658. Di unduh dari

https://www.google.co.id/search?q=Aerob ic + Exercise+Reduces + Blood + Pressure + in + Resistant + Hypertension\&oq $=$ Aerobic $+E$ xercise+Reduces + Blood + Pressure + in + Re sistant + Hypertension\&sourceid $=$ chrome $\&$ ie $=$ UTF-8 pada tanggal 04 Maret 2017, jam 01:01 WIB

6. Lumempouw \& Wungouw. (2016). Pengaruh senam prolanis terhadap penyandang hipertensi. Vol $4 ; 1$ di unduh pada tanggal 04 Maret 2017, jam 12:07 WIB

7. Triwibowo, Frilasari, dkk. (2015). Pengaruh senam ergonomil terhadap tekanan darah pada penderita hipertensi di desa sumber agung kecamatan jatirejo Mojokerto. Media publikasi di unduh pada tanggal 18 Maret 2017, jam 09:45 WIB

8. Dharma, K. (2015). Metodologi Penelitian Keperawatan : Panduan Melaksanakan dan Menerapkan Hasil Penelitian. Trans Info Media, Jakarta

9. Notoatmodjo. (2012). Metodologi penelitian kesehatan. Rineka cipta, Jakarta

10. Supardi, Rustika. (2013). Buku ajar metodologi riset keperawatan. CV trans ifo media, Jakarta

11. Widyanto \& Triwibowo. (2013). Trend disease ; Trend penyakit saat ini. CV. Trans info media, Jakarta

12. Fetriwahyuni, dkk, (2015). Pengaruh senam aerobik low impact terhadap tekanan

darah penderita hipertensi di unduh pada tanggal 18 Maret 2017, jam 09:45 WIB

13. Husnul. (2011). Bergembira melakukan senam irama. PT wadah ilmu, Jakarta

14. Griwijoyo. (2017). Fisiologi kerja dan olahraga ; fungsi tubuh manusia pada kerja dan olahraga. Kharisma putra utama offset, Jakarta

15. Anggraini. (2015). Pengaruh senam aerobik terhadap tekanan darah ibu-ibu penderita hipertensi didesa Kwarsan Nogotirto Sleman Yogyakarta. Naskah publikasi di unduh dari http://opac.unisay ogya.ac.id/12/1/NASKAH\%20PUBLIKA SI.pdf pada tanggal 04 Maret 2017, jam
12:09

WIB.2014.http://jkb.ub.ac.id/index.php/jk b/article/view/523 di unduh tanggal 3 Maret 
